\title{
The Relationship Between Use of Smartphone and Student's Interest in Reading Book
}

\author{
Vina Octaviani ${ }^{\mathrm{a} *}$, Nanang Martono ${ }^{\mathrm{a}}$ \\ ${ }^{\text {a }}$ Faculty of Social Science and Political Science, Universitas Jenderal Soedirman, Purwokerto, Indonesia \\ vina.octaviani@mhs.unsoed.ac.id*; nanang.martono@unsoed.ac.id \\ *Corresponding author
}

\begin{tabular}{l}
\hline Article Info \\
\hline Article history: \\
Received Apr 15, 2021 \\
Revised Oct 27, 2021 \\
Accepted Oct 28, 2021 \\
\hline
\end{tabular}

Keywords:

Smartphone

Student's Reading Interest

\begin{abstract}
Smartphones have become an essential part of students' daily lives. Students use smartphones for various activities. Through smartphones, students can access various service sites that provide material resources such as scientific journals, scientific articles, eBooks, and others. This article aims to explain the relationship between the use of smartphones and students' interest in reading books. In this research, the book in question is an eBook. The quantitative survey method was used in this study. The target of this research is students of class XII at VHS Negeri 1 Ciamis with a sample size taken $42 \%$ of the total number of 557 students, that is 233 people. The researcher used Kendall's Tau correlation test as a data analysis method. The correlation value of 0.063 and the significance value of 0.314 in this research results indicate that there is no significant relationship between the variables. The findings of this study show that there is a positive relationship between students' interest in reading books and their use of smartphones, but the relationship between the two variables is very weak and insignificant at the 0.05 level, so the relationship cannot be generalized. This means that students rarely use smartphones to access eBooks but to use them for other purposes instead.
\end{abstract}

This is an open access article under the CC BY-SA license.

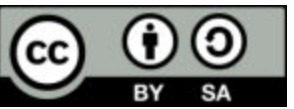

\section{Introduction}

Reading is one of the four language skills that are needed in human life. Reading is an important skill possessed by humans because reading can be used as a way to communicate. Through reading, we can understand and understand the intentions and feelings of other people who write it. Reading can also be interpreted as a process of recognizing words and combining them in structured sentences so that they have perfect meanings (Rohman, 2017). According to Samniah (2016), reading can also be interpreted as a process of understanding the meaning contained in written words by speaking orally or in the heart. Reading is an important key for the progress of a nation, therefore people are expected to have a high interest in reading activities. Somadayo (in Triatma, 2016) says that every aspect of human life involves reading. For this reason, various efforts must be to increase public interest in reading. 
Reading interest is an inner drive that influences behavior and actions that give birth to interest, attention, desire, and feelings of pleasure towards reading activities (Rahma et al., 2015; Dahlan, 2008). Interest in reading is one of the important components that determine the quality of the nation (Kasiyun, 2015). The higher the reading interest of individuals in a country, the quality of human resources in a country will be high, and vice versa.

The results of PISA (Program for International Student Assessment) can be one of the things that show that the problem of reading interest is still a serious problem faced by Indonesia. PISA is one of the ability and knowledge assessment programs organized by the Organization for Economic Co-operation and Development (OECD) which measures students' abilities in several literacy areas, one of which is reading literacy (Hasanah Warjana, 2019; Hawa Putra, 2018; Pratiwi, 2019). In 2018, the average reading score of students in Indonesia decreased from 397 to 371. This score is below the OECD country's average score of 487 (PISA 2018 Result-OECD, 2019). This decrease has caused Indonesia to be ranked 72nd out of 77 countries that participated in PISA in 2018. The PISA data indirectly shows that Indonesian students' reading interest is still very low (Nugrahanto Zuchdi, 2018; Hidayah, 2017).

Interest in reading can be grown from an early age. This process increases when children enter school age, so schools have a role in increasing this interest in reading. Efforts to increase reading interest in schools are usually carried out through the medium of books as a source of knowledge. Therefore, schools facilitate students by providing textbooks and other reading books as a medium for reading. The higher the intensity of reading that student have, the level of knowledge and insight of students will also increase (Susanti, et al, 2018). According to Rahim (2011), students must have a high interest in reading to gain broad insight and knowledge so that they can follow the development of science and technology (Tantri Dewantara, 2017).

Thresia (2014) in her research shows that there are still many students who make reading activities a way to fill their spare time. Most of the students thought that they liked reading and some said that they had made reading a hobby. This shows that the enthusiasm for reading activities among students is still quite high.

In today's digital era, students participate as consumers of technical development products, such as smartphones, in addition to reading. The presence of a smartphone in students' daily lives is considered highly crucial at this moment (Alhady, et al. 2018). Smartphones have evolved into versatile devices that are no longer just a method of communication but also a way of life (Rahma, 2018). This happens because smartphones provide many interesting features, such as social media, games, music, and other entertainment facilities. At this time, it is not uncommon for students to bring smartphones to school and use them to access these media (Sobon Mangundap, 2019). The features that are presented in smartphones provide special pleasure for students because many interesting things can be accessed through smartphones.

Susanti Santi (2019) in her research said that interest in reading among teenagers is still very low. They are more concerned with playing games, accessing social media, hanging out in cafes with friends rather than reading books, let alone coming to the library or community reading park in their neighborhood. The results of this study indicate that most teenagers still use smartphones to access entertainment media, even though in addition to providing entertainment features, smartphones also provide features that can be used to assist and simplify the learning process and make it easier for students to find information, become a source of reading that can provide information, wider knowledge and insight apart from books. Fatimah Mufti (2014) emphasized that smartphones can be used as one of the 
interesting learning media because students can learn and read in a different way than usual. Students can access reading materials on the internet in the form of eBooks or others easily by using a smartphone.

Research conducted by Nasution, et al (2017) shows that students' motives for having smartphones are due to the need for applications that can be used to support learning and reading activities. Likewise, with the use of smartphones, the results of this study indicate that students use smartphones for positive things, namely for learning, reading, fostering good relationships with peers. Thus, smartphones at this time are expected to be able to grow and increase interest in reading in students.

This research was carried out at SMK (Vocational High School). Vocational High School is one of the educational institutions in charge of creating human resources with the capacity, skills, and expertise to develop their performance if they enter the workforce immediately (Edi, et al 2017). This shows that SMK is not intended to prepare graduates to continue their education to the tertiary level, but is intended to prepare students to work either independently or to fill existing job opportunities. Vocational students are more focused on training their skills and abilities in the field of majors taken. Therefore, Vocational High School students more often do learn with practical methods and go directly to the field. In contrast to high school students who are public schools with a learning model that focuses more on theory learning.

This research was conducted in a Vocational High School. Based on the observations that have been made, it has adequate reading facilities by establishing libraries and literacy gazebos in schools. The construction of these facilities ultimately led the school to win second place in the Best Library at the West Java level in 2019. This study aims to explain how reading interest among vocational students differs from that of general students, as well as the relationship between smartphone use and reading interest.

\section{Method}

The design of this study is a correlational study which is a study to examine the relationship between variables. The research method used in this study is a survey method. The survey is a research method used to obtain data about beliefs, opinions, characteristics, behavior, relationships between variables and to test several hypotheses from samples taken from certain populations. The data collection technique for this survey is usually using a questionnaire (Sugiyono, 2019). The data analysis method in this study used the tau Kendall correlation test and the data were presented using a cross table. This study is associative because this study aims to explain the relationship between variables.

In this study, the population in question is the number of class XII students consisting of majors in Accounting and Institutional Finance, Online Business and Marketing, Office Automation and Governance, Hospitality, Catering, Multimedia, and Software Engineering. The sampling technique used in this study was Proportional Stratified Random Sampling.

Table 1. Total Population and Sample

\begin{tabular}{llcc}
\hline \multirow{2}{*}{ Number } & \multicolumn{1}{c}{ Majors } & Population and Sample & \\
\cline { 2 - 4 } & \multicolumn{1}{c}{ Pccounting and Institutional } & 140 & Sample \\
2 & $\begin{array}{l}\text { Finance } \\
\text { Online Business and }\end{array}$ & 104 & 44 \\
3 & $\begin{array}{l}\text { Marketing } \\
\text { Office Automation and } \\
\text { Governance }\end{array}$ & 108 & 45
\end{tabular}




\begin{tabular}{llcc}
4 & Hospitality & 70 & 29 \\
5 & Catering & 67 & 29 \\
6 & Multimedia & 34 & 14 \\
7 & Software Engineering & 34 & 14 \\
& Total & $\mathbf{5 5 7}$ & $\mathbf{2 3 3}$ \\
\hline
\end{tabular}

Primary Data Sources (2021)

The population in this study was 557 students, so the error rate of the sample used was $5 \%$ and the results of the calculations could be rounded off to get conformity. Based on the calculation results, the number of samples in this study was rounded up to 233 students, or about $42 \%$ of the total class XII students of SMK Negeri 1 Ciamis in all majors.

This study aims to determine how the relationship between the use of smartphones and students' interest in reading, the hypothesis in this study is that there is a positive relationship between the use of smartphones and the interest in reading books of students at SMK Negeri 1 Ciamis.

\section{Results and Discussion}

An instrument (question list) in the questionnaire is declared valid if the items in the question can measure exactly what is to be measured. The results of the instrument validity test in this study are as follows.

\section{X1 Validity Test}

Correlations

\begin{tabular}{|c|c|c|c|c|c|}
\hline & & $\begin{array}{c}\text { Q1. } \\
\text { KepemilikanT } \\
\text { P }\end{array}$ & $\begin{array}{c}\text { Q4. } \\
\text { TPuntukEboo } \\
\mathrm{k}\end{array}$ & Q8.1.E_Book & CompX1 \\
\hline \multirow[t]{3}{*}{ Q1.KepemilikanTP } & Pearson Correlation & $a^{a}$ & $\mathrm{~d}^{\mathrm{a}}$ &.$^{a}$ & \\
\hline & Sig. (2-tailed) & & & . & \\
\hline & $\mathrm{N}$ & 233 & 233 & 233 & 233 \\
\hline \multirow[t]{3}{*}{ Q4.TPuntukEbook } & Pearson Correlation & $a^{a}$ & 1 & $.833^{\mathrm{m}}$ & $.934^{\mathrm{m}}$ \\
\hline & Sig. (2-tailed) & & & .000 & .000 \\
\hline & $N$ & 233 & 233 & 233 & 233 \\
\hline \multirow[t]{3}{*}{ Q8.1.E_Book } & Pearson Correlation & $i^{a}$ & $.833^{\prime \prime}$ & 1 & $.975^{\mathrm{m}}$ \\
\hline & Sig. (2-tailed) & & .000 & & .000 \\
\hline & $\mathrm{N}$ & 233 & 233 & 233 & 233 \\
\hline \multirow[t]{3}{*}{ CompX1 } & Pearson Correlation & $i^{a}$ & $.934^{\mathrm{m}}$ & $.975^{11}$ & 1 \\
\hline & Sig. (2-tailed) & & .000 & .000 & \\
\hline & $\mathrm{N}$ & 233 & 233 & 233 & 233 \\
\hline
\end{tabular}

th. Correlation is significant at the 0.01 level (2-tailed).

a. Cannot be computed because at least one of the variables is constant

\section{Y Validity Test}

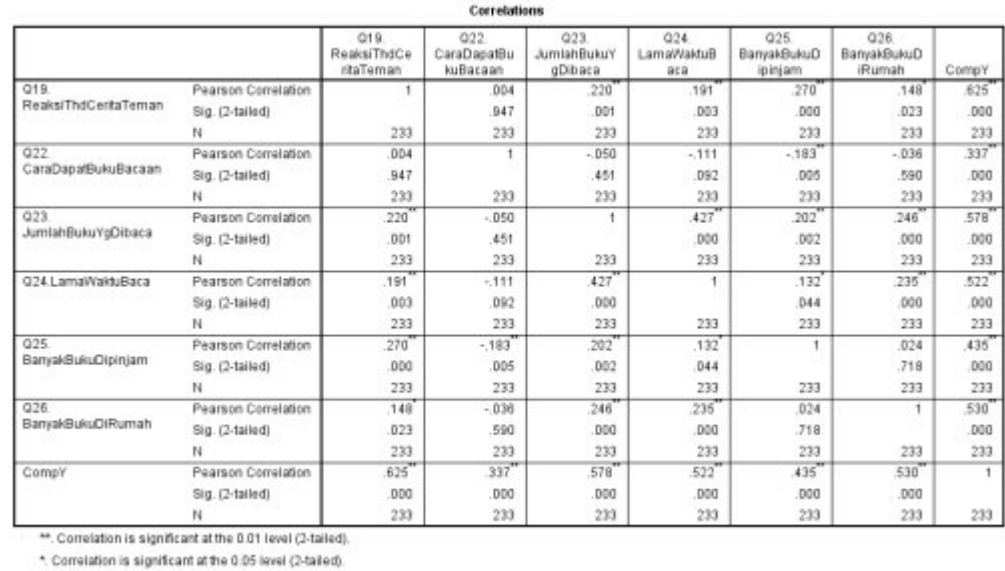

Based on the results of the instrument validity test that has been presented, it shows that the question items tested are declared valid based on testing using the product-moment 
correlation test. Research conducted by Irhandayaningsih (2017) with the title "The effect of smartphone use on reading interest in SMA Negeri 1 Semarang students" clearly shows that the research target is high school students (SMA).

In this study, the research targets used were SMK students. As for the results of the questionnaire that has been carried out at SMK Negeri 1 Ciamis, 233 respondents have been obtained, namely class XII students who are male and female. The following is a table that shows the characteristics of respondents by gender.

Table 2. The Characteristics of Respondents by Gender

\begin{tabular}{llccc}
\hline \multirow{2}{*}{ Number } & \multicolumn{3}{c}{ The Characteristics of Respondents } \\
\cline { 2 - 4 } & & Gender & Frequency & Percentage (\%) \\
\hline 1 & Male & 46 & 19,7 \\
2 & Female & 187 & 80,3 \\
& Total & $\mathbf{2 3 3}$ & $\mathbf{1 0 0}$ \\
\hline
\end{tabular}

Primary Data Sources (2021)

Table 2 shows that as many as 233 students are willing to fill out this research questionnaire. Characteristics of respondents who filled out the questionnaire were dominated by female students as many as 187 people $(80.3 \%)$, while male students who filled out $46(19.7 \%)$.

These results indicate that female students tend to be more active in carrying out activities through smartphones and tend to be more active in socializing with their peer group. The responses to the distributed surveys also reveal the characteristics of the respondents based on the majors. The following table shows the characteristics of responders based on their majors.

Table 3. The Characteristics of Respondents on Their Majors

\begin{tabular}{llcc}
\hline \multirow{2}{*}{ Number } & \multicolumn{1}{c}{ Majors } & The Characteristics of Respondents & Percentage \\
\cline { 2 - 4 } & Accounting and Institutional & 58 & 24,9 \\
2 & Finance & & 18,9 \\
& Online Business and & 44 & \\
3 & Marketing & & 19,3 \\
& Office Automation and & 45 & 12,4 \\
4 & Governance & 29 & 12,4 \\
5 & Hospitality & 29 & 6 \\
6 & Catering & 14 & 6 \\
7 & Multimedia & 14 & $\mathbf{1 0 0}$ \\
& Software Engineering & $\mathbf{2 3 3}$ & \\
\hline
\end{tabular}

Primary Data Sources (2021)

Table 3 shows that respondents who filled out the questionnaire were dominated by students from the Department of Accounting and Institutional Finance because the department consisted of 5 classes. Then, the least number of respondents who filled out the questionnaire was the Department of Multimedia and Software Engineering because each department only had 1 class.

The findings of the questionnaires that were circulated also collect data showing the average age of the respondents is 17-18 years, in addition to getting gender-based characteristics of respondents. The characteristics of respondents by age are shown in the table below.

Table 4. The Characteristics of Respondents by Age

Number The Characteristics of Respondents




\begin{tabular}{llccc}
\hline & Age & Frequency & Percentage $(\mathbf{\%})$ \\
\hline 1 & 17 years & 137 & 58 \\
2 & 18 years & 96 & 41,2 \\
& Total & $\mathbf{2 3 3}$ & $\mathbf{1 0 0}$ \\
\hline Primary Data Sources $(2021)$ & &
\end{tabular}

Primary Data Sources (2021)

Table 4 shows that the characteristics of respondents based on age are dominated by students aged 17 years with a frequency of 137 people (58\%). That is, the majority of respondents in this study are students who are entering a transition period from adolescence to adulthood because at this age students experience many developments such as development in cognitive, emotional, psychological, and social aspects.

The presence of smartphones has its meaning for various fields in human life, not least for the field of education, especially students. The sophistication offered by smartphones such as the availability of the internet can be used by students to help the learning process. Among students, smartphones have become a multifunctional thing. The use of smartphones among students can be based on two things, first, as a lifestyle, meaning that students use smartphones to follow trends or are more active in using social media such as Instagram, Twitter, FaceBook, and others. Second, as a necessity, it means that students use smartphones to find information about many things, use them as a learning resource, use it to find and read additional material and other things. This means that smartphones have become one of the important needs for students to have because it has many benefits. The following is a table of respondents' perceptions of the benefits of smartphones.

Table 5. Respondents Perceptions of The Benefits of Smartphones

\begin{tabular}{llcc}
\hline \multirow{2}{*}{ Number } & \multicolumn{3}{c}{ Respondents Perceptions } \\
\cline { 2 - 4 } & \multicolumn{1}{c}{ Benefits of Smartphones } & Frequency & Percentage (\%) \\
\hline 1 & Comunicating & 233 & 100 \\
2 & Looking for and getting & 233 & 100 \\
& information & & 24 \\
3 & Helping the learning process & 177 & 19,7 \\
4 & Entertaiment Media & 187 & 40,3 \\
5 & Doing business & 139 & \\
\hline
\end{tabular}

The results from table 5 show that the majority of respondents stated that the benefits of smartphones are to communicate and seek and obtain information. In addition, the least stated benefit of smartphones by respondents is for business. 139 respondents stated that smartphones have benefits for doing business. This means that the majority of respondents still use smartphones for more general things and not many respondents have thoughts or use smartphones for profit.

Based on these results, it shows that smartphones have many benefits so that their presence at this time is very important to help students carry out activities in daily life. The following table shows the activities carried out by respondents using smartphones.

Table 6. Respondents Activities

\begin{tabular}{llcc}
\hline \multirow{2}{*}{ Number } & \multicolumn{3}{c}{ Respondents Ativites via Smartphone } \\
\cline { 2 - 4 } & \multicolumn{1}{c}{ Activities Undertaken } & Frequency & Percentage (\%) \\
\hline 1 & Comunicating with others & 233 & 100 \\
2 & Seeking information & 233 & 100 \\
3 & Accessing eBooks & 139 & 59,7 \\
4 & Accessing entertainment & 233 & 100 \\
& media & 176 & 75,5 \\
5 & Creating (editing & & \\
& photos/videos) & 190 & 81,5 \\
\hline
\end{tabular}




\begin{tabular}{llll}
\hline 7 & Online shopping & 152 & 65,2 \\
8 & Online learning & 186 & 79,8 \\
\hline \multicolumn{2}{l}{ Primary Data Sources (2021) }
\end{tabular}

Table 6 shows that the activities carried out by the majority of respondents through smartphones are to communicate with others, seek information, and access entertainment media. This means that respondents prioritize the use of smartphones for more general and important things in their daily lives. On the other hand, the activities carried out by a minority of respondents are accessing eBooks, which are 139 (59.7\%) people. These results indicate that in addition to reading directly from books, respondents can also carry out reading activities using smartphones, namely through eBooks or electronic books. Respondents chose to find and carry out reading activities through eBooks for several reasons. The following table shows the reasons for respondents to do reading activities through eBooks.

Table 7. Reason for Reading eBooks

\begin{tabular}{|c|c|c|c|c|c|c|}
\hline \multirow{2}{*}{ Number } & \multicolumn{6}{|c|}{ Frequency and Percentage $(\%)$} \\
\hline & Reason & Strongly Agree & Agree & Disagree & Strongly Disagree & Total \\
\hline 1 & $\begin{array}{l}\text { Diverse reading } \\
\text { sources }\end{array}$ & $87(62,6)$ & $529(37,4)$ & 0 & 0 & $\begin{array}{c}139 \\
(100)\end{array}$ \\
\hline 2 & Faster search & $66(47,5)$ & $66(47,5)$ & $7(5)$ & 0 & $\begin{array}{l}139 \\
(100)\end{array}$ \\
\hline 3 & More practical & $73(52,2)$ & $65(46,8)$ & $1(0,7)$ & 0 & $\begin{array}{l}139 \\
(100)\end{array}$ \\
\hline 4 & $\begin{array}{l}\text { Can be accessed } \\
\text { anytime }\end{array}$ & $23(17,3)$ & $61(43,9)$ & $50(36)$ & $4(2,9)$ & $\begin{array}{l}139 \\
(100)\end{array}$ \\
\hline 5 & Easy to carry & $78(56,1)$ & $61(43,9)$ & 0 & $4(2,9)$ & $\begin{array}{l}139 \\
(100)\end{array}$ \\
\hline 6 & Easy to share & $63(45,3)$ & $71(51,1)$ & $5(3,6)$ & 0 & $\begin{array}{c}139 \\
(100)\end{array}$ \\
\hline 7 & More economical & $7(5)$ & $51(36)$ & $69(49,6)$ & $12(8,6)$ & $\begin{array}{l}139 \\
(100)\end{array}$ \\
\hline 8 & More eco-friendly & $59(42,4)$ & $75(54)$ & $5(3,6)$ & 0 & $\begin{array}{l}139 \\
(100)\end{array}$ \\
\hline
\end{tabular}

Primary Data Sources (2021)

Table 7 shows that the majority of respondents agree that the reasons for reading through eBooks are due to the availability of various reading sources, the search for reading materials is relatively faster, more practical, and easy to carry and the reading materials are easy to share with others. This reason shows that respondents like things that are more practical and relatively fast because it will save more time because the process does not spend a lot of time. Likewise, with the process of distributing reading materials digitally, eBooks are considered more environmentally friendly. This is indicated by as many as $75(32.2 \%)$ respondents who agree with the reason that reading through eBooks is more environmentally friendly. This means that the reading material does not use paper so that it will minimize the use of paper. In addition, 5 (2.1\%) respondents did not agree with this reason because they think that smartphone devices can also become environmentally unfriendly waste when they are not used.

Reading through eBooks is the choice of the majority of respondents for several reasons that have been described previously, but table 7 shows that as many as 69 (29.6) respondents tend to disagree because eBooks are more economical than printed books. This means that respondents think that there are still many paid eBook sites. devices can also become environmentally unfriendly waste when they are not used. Many eBook sites initially provide free services, but there is little reading material available and if you want to access it in full, 
usually the eBook site will offer or ask users to make payments and become customers of the site.

In addition to showing the majority of respondents who use smartphones to read through eBooks, table 7 also shows that there are as many as 94 (40.3\%) respondents who do not use smartphones to access eBooks or do reading activities through eBooks. They did not do so for several reasons which have been summarized and presented in the following table.

Table 8. Respondents Reasons for not Accessing eBook

\begin{tabular}{llcc}
\hline \multirow{2}{*}{ Number } & \multicolumn{1}{c}{ Reasons } & Frequency & Percentage (\%) \\
\cline { 2 - 4 } 2 & $\begin{array}{l}\text { Not interested } \\
\text { Uncomfortable and not } \\
\text { focusing on reading }\end{array}$ & 6 & 6,4 \\
& $\begin{array}{l}\text { Mpre happu reading through } \\
\text { printed book } \\
\text { Total }\end{array}$ & 17 & 75,5 \\
& & $\mathbf{9 4}$ & 18,1 \\
\hline
\end{tabular}

Primary Data Sources (2021)

Table 8 shows that the majority of respondents, as many as $71(30.5 \%)$ reasoned that they were uncomfortable and unfocused when reading through eBooks. Then as many as 17 $(7.3 \%)$ respondents stated that they prefer to read through books than eBooks. Then as many as $6(2.6 \%)$ respondents said they were not interested in reading through eBooks. Based on the results that have been described, it can be concluded that the majority of respondents who do not do reading activities through eBooks are reasoned because of the discomfort in the eyes when used to read through eBooks because the light from smartphones sometimes makes the eyes tired which will then cause the view to not focus on the material. which is being read. The majority of respondents also stated that they prefer to read through printed books because they feel more comfortable in their eyes. These results contradict the results of research conducted by Idhamani (2020) which states that groups of school students with an age range of 15-20 years have a higher reading interest in eBooks than physical books. This is because students can operate smartphones so that they can access and read eBooks easily via smartphones and students are the millennial generation who currently prefer digital-based things, including reading.

Respondents have different times in using their smartphone devices. They have their intensity or time division in accessing features in their smartphones, such as using them to read eBooks and to access social media or other features, as shown in the following table.

Table 9. The Intensity of Accessing eBooks

\begin{tabular}{lccc}
\hline \multirow{2}{*}{ Number } & \multicolumn{3}{c}{ Intensity Respondents of Accessing EBooks } \\
\cline { 2 - 4 } & Duration of Time & Frequency & Percentage (\%) \\
\hline 1 & $0-1$ hour/day & 129 & 55,4 \\
2 & $1-2$ hour/day & 59 & 25,3 \\
3 & $2-3$ hour/day & 40 & 17,2 \\
4 & $>3$ hour/day & 5 & 2,1 \\
& Total & $\mathbf{2 3 3}$ & $\mathbf{1 0 0}$ \\
\hline
\end{tabular}

Primary Data Sources (2021)

Table 9 shows that the majority of respondents use smartphones to access eBooks in only $0-1$ hours while those who access eBooks for more than 3 hours are only 5 respondents. This shows that respondents do not spend time using their smartphones to read eBooks, but respondents more often use smartphones to access entertainment media. The following table shows the duration of smartphone use by respondents.

Table 10. Duration of Smartphone Use 


\begin{tabular}{llcc}
\hline \multirow{2}{*}{ Number } & \multicolumn{3}{c}{ The Intensity of Accessing Entertainment Media } \\
\cline { 2 - 4 } & \multicolumn{1}{c}{ Duration of Time } & Frequency & Percentage (\%) \\
\hline 1 & $0-1$ hour/day & 20 & 8,6 \\
2 & $1-2$ hour/day & 58 & 24,9 \\
3 & $2-3$ hour/day & 97 & 41,6 \\
4 & $>3$ hour/day & 58 & 24,9 \\
& Total & $\mathbf{2 3 3}$ & $\mathbf{1 0 0}$ \\
\hline
\end{tabular}

Primary Data Sources (2021)

Table 10 shows that as many as 97 (41.6\%) respondents spend about 2-3 hours/day accessing entertainment media using their smartphones. Respondents more often use their smartphones to access social media, play games, watch videos, and others compared to accessing and reading eBooks. As for the search for reading materials or materials, respondents tend to search for materials more often or read through reading sites that can be searched through a google search rather than through an eBook application.

Perceptions about the benefits of reading are very diverse, according to each individual. Respondents' perceptions of the benefits of reading can be seen in the following table 10:

\begin{tabular}{llcc}
\multicolumn{4}{c}{ Table 11. The Benefits of Reading } \\
\hline \multirow{2}{*}{ Number } & \multicolumn{1}{c}{ The Benefits of Reading according to Respondents } \\
\cline { 2 - 4 } & \multicolumn{1}{c}{ The Befits } & Frequency & Percentage (\%) \\
\hline 1 & $\begin{array}{l}\text { Increase knowledge and } \\
\text { broaden insight }\end{array}$ & 20 & 8,6 \\
2 & $\begin{array}{l}\text { Filling free time } \\
\text { Improve brain ability and } \\
\text { increase vocabulary }\end{array}$ & 58 & 24,9 \\
& Total & 97 & 41,6 \\
& & $\mathbf{2 3 3}$ & $\mathbf{1 0 0}$ \\
\hline
\end{tabular}

Primary Data Sources (2021)

Table 11 shows that all 233 respondents $(100 \%)$ stated that reading can increase knowledge and broaden horizons. In addition, reading is also beneficial for improving memory and brain abilities as stated by 141 (60.5\%) respondents. Then $140(60.1 \%)$ respondents also stated that reading can also be used to fill spare time so that the existing spare time is not wasted.

Based on these results, it means that by reading, we can find out extraordinary things, know and understand how the values of life are implied through writing. In addition, reading can also be useful to train the ability and memory of the brain and increase vocabulary. Reading activities should be done often so that we can find out a lot of information that can help us carry out activities and improve our abilities so that we can compete with others.

The results of this study were analyzed using the tau Kendall correlation test and presented using cross-tabulation. The results of the cross-table calculation aim to determine the direction of the relationship between one variable and another. The relationship between these variables can be in the form of a positive (unidirectional) or negative (opposite direction) relationship. The results of the cross-tabulation of the variable of smartphone use with interest in reading books (eBooks) in this study are as follows.

Table 12. Cross Tabulation Result

\begin{tabular}{|c|c|c|c|c|}
\hline \multirow{2}{*}{$\begin{array}{l}\text { The Use of } \\
\text { Smartphone }\end{array}$} & \multicolumn{4}{|c|}{ Students Reading Interest } \\
\hline & Low & Medium & High & Total \\
\hline Low & $29(30,9 \%)$ & $56(59,6 \%)$ & $9(9,6 \%)$ & $94(100 \%)$ \\
\hline Medium & $2(40 \%)$ & $3(60 \%)$ & $0(0 \%)$ & $5(100 \%)$ \\
\hline High & $35(26,1 \%)$ & $85(63,4 \%)$ & $14(10,4 \%)$ & $134(100 \%)$ \\
\hline Total & $66(28,3 \%)$ & $144(61,8 \%)$ & $23(9,9 \%)$ & $233(100 \%)$ \\
\hline
\end{tabular}


Based on table 12, the results of the cross table between the variables of smartphone use (X1) and students' interest in reading books (Y) show that respondents who use smartphones to access eBooks in the low category tend to have moderate reading interest $(59.6 \%)$. Respondents who use smartphones to access eBooks in the medium category tend to have a moderate interest in reading $(60.0 \%)$ and respondents who use smartphones to access eBooks in the high category tend to have moderate reading interest $(63.4 \%)$. These results indicate that the direction of the relationship between the variables of the use of smartphones and the interest in reading books (eBooks) of respondents is the same. The use of smartphones to read eBooks in low, medium, and high categories forms a moderate interest in reading eBooks. That is, there are other factors besides the use of smartphones that can shape and increase respondents' interest in reading books.

In a study conducted by Irhandayaningsih (2017), an analysis of the effect of smartphone uses on students' reading interest uses the multiple linear regression analysis methods because it aims to find the effect between variables. While this study aims to explain how the relationship between the variables of smartphone utilization and students' interest in reading books, for that the statistical test tool used in this study is the tau Kendall correlation test. Based on the results of the analysis test using the Tau Kendall correlation, it can be seen that the variables of Smartphone Utilization (for EBooks) and Interest in Reading Books (EBooks) have a very weak relationship. This is indicated by the correlation value (Correlation Coefficient) of 0.048. The significance value of the two variables shows a result of 0.441 , meaning that between the variables of using smartphones and reading books there is a very weak relationship. This shows that although the majority of respondents have accessed and read through eBooks, in this study the frequency of students reading through eBooks is quite rare. This means that respondents do not always focus and require themselves to do reading activities only through eBooks, but respondents also carry out reading activities through reading pages available on the internet.

Respondents tend to read eBooks when there is an order from the teacher at school. Likewise, the intensity of reading time through eBooks by respondents in this study shows that the survey results show that the majority of respondents read time through eBooks only around 0-1 hours. Some of the factors that influence this, one of which is a paid eBook site, meaning that users cannot get full access to the eBook so that the available reading materials tend to be incomplete or only contain summaries. The results of research conducted by Isnaeni et al (2016), students are more dominant in using the internet search column to obtain information and reading sources related to school lessons, school assignments, and others.

EBook reading activities carried out by students tend to be carried out in not enough time, which is less than one hour. This happens because most students tend to read eBooks only when getting orders from the teacher and only when getting assignments. Students who do reading activities either through eBooks or via the internet tend to do it by scanning the reading material, meaning that students do not read the reading material as a whole, but only look for the essence of the reading. This is done because of the discomfort and eyes that get tired quickly when staring at the smartphone screen for a long time. In addition, the number of notifications that appear can interfere with concentration when reading so that understanding of the material will decrease. Makdis (2020) in his research states that reading apart from causing discomfort to the eyes, when reading through eBooks online can also often be disturbed by the large number of notifications that enter the smartphone device or even the temptation from other facilities such as social media, games, music, a film that can break your concentration while reading eBooks. 
However, the direction of the relationship between the variable of smartphone uses and interest in reading books is positive, which means that if students use smartphones to access and read eBooks more often, the students' reading interest will be higher. The benefits obtained in the use of smartphones can be in the form of positive and negative benefits. The better the use of smartphones, the better the benefits, and vice versa. One of the positive benefits obtained is that it can be used to access and read eBooks. EBooks or electronic books can be used as an alternative source of reading that can be used by all groups, especially students. EBooks or digital books have many benefits that students can enjoy.

With the various advantages and attractions provided by the eBook, it is expected to be able to increase students' reading interest. Students can take advantage of the eBook application when they experience problems with a limited reading of printed books. EBooks provide interesting features for readers such as providing audio, video, and simulation features that can be used to facilitate readers to better understand the material presented in more depth (Muhammad, et al, 2017). In this study, the majority of respondents have accessed and read materials through eBooks. The main factor in using the eBook is that it is practical and easy to carry anywhere, so students do not have to bother and object when bringing reading material because the eBook is stored in a smartphone device. These results are by Sukardi's research (2020) which states that eBooks are more in demand because they are practical and also more attractive because they use electronic media.

\section{Conclusion}

Based on the results of the data analysis that has been presented, it can be concluded that the hypothesis which states that there is a positive relationship between the variable of smartphone use and interest in reading books (EBooks) of students at SMK Negeri 1 Ciamis is accepted. The correlation value of 0.048 and a significance value of 0.441 indicate that the relationship between variables is not significant. The relationship between the two variables is positive but very weak and not significant at the 0.05 level, which means that the relationship between variables cannot be generalized.

These results indicate that the respondents in this study did not focus and did not prioritize the use of smartphones to access e-books. They do a lot of activities through smartphones, either for entertainment or to help the learning process other than through ebooks. In this study, the author provides several suggestions to several parties as follows:

\section{For Schools}

1) Schools are expected to provide a supportive reading environment for students to do reading activities together with their peers. In addition, schools are also expected to be able to add library facilities, because schools are educational institutions as well as efficient environments to create an atmosphere of high reading literacy.

2) It is hoped that schools can add library facilities by providing online library services that contain eBooks, journals, articles, and other reading sources that can be accessed for free by students so that students can access them when outside of school.

\section{For Students}

For all students, should be more aware of the importance of doing activities, reading, and are expected to be more selective in choosing a friendly environment. Students should be able to distinguish between a friendly environment that has a positive impact and an environment that has a negative impact. 


\section{For Further Research}

The limitation of this research is that it was only conducted at the SMK level, with the results showing that students still lack interest in reading. One of the reasons is because as vocational students, they are more focused on honing their skills through hands-on practice, rather than reading theory through books. Therefore, further research is recommended to be carried out at the high school level. High school students in learning more by analyzing and reading theoretical things, so that knowledge and references reading more too. This can be one of the variables that are related to or affect students' reading interest.

\section{References}

Alhady, N. C., Salsabila, A. F., Azizah, N. N. (2018). The Use of Smartphones in the Learning Construction of MTS Negeri 7 Jakarta Model Students. Al-Izzah Journal of Research Results, 13(2), 240-254.

Dahlan, M. (2008). Motivation for Reading Interest. Junal Iqra', 2(1), 21-32.

Fatimah, S., Mufti, Y. (2014). Development of Android-Based Smartphone Science-Physics Learning Media to Strengthen Students' Science Character. Kaunia Journal, 10(1), 59-64.

Hasanah, U., Warjana. (2019). Development of Reading Literacy Learning To Improve Students' Reading Power. Journal of Media Librarian, 26(2), 129-139

Hawa, A. M., Putra, L. V. (2018). PISA For Indonesian Students. Journal of Primary and Childern's Education, 1(1), 1-8.

Hidayah, A. (2017). Development of Type The BIG6 TIL (The Information Literacy) Model in the Learning Process as an Effort to Grow a Literacy Culture in Schools. Journal of Research and Reasoning, 4(1), 623-635.

Idhamani, A. P. (2020). Impact of Information Technology on Students' Reading Interest. Journal Library, 11(1), 35-41.

Irhandayaningsih, A \& Etnanta, CY. (2017). The Effect of Smartphone Use on Reading Interest of SMA Negeri 1 Semarang Students. Journal of Library Science, 6(1), 371380

Isnaeni, M. (2016). Media Communication in Increasing Interest in Reading SMAN 9 Kendari Students. UHO Journal of Communication Science, 1(3), 1-15.

Kasiyun, S. (2015). Efforts to Increase Reading Interest as a Means to Educate the Nation. Indonesian Pena Journal, 1(1), 79-95.

Makdis, N. (2020). The Use of EBooks in the Digital Age. Journal of Al-Maktabah, 19(1), $77-84$.

Martono, N. (2016). Quantitative Research Methods Content Analysis and Secondary Data Analysis. Jakarta PT. RajaGrafindo Persada. 
Muhammad, M., Rahadian, D., Safitri, E. R. (2017). Using Android-Based Digital Books to Improve Motivation and Reading Skills in Arabic Lessons. Pendagogia Journal of Educational Sciences, 15(2), 170-182.

Nasution, J. A., S, N., Alizamar. (2017). Motives of Students Owning Smartphones and Their Use. Indonesian Journal of Educational Research, 3(2), 15-29.

Nugrahanto, S., Zuchdi, D. (2018). Indonesia PISA Result and Impact on The Reading. International Conference on Interdisciplinary Language, Literature and Education. 297, pp. 373-377. Yogyakarta, Indonesia Atlantis Press.

OECD. (2019, December 3). PISA 2018 Results. Retrieved from PISA 2018 Results: https //www.oecd.org/pisa/Combined_Executive_Summaries_PISA_2018.pdf

OECD. (2019, December 3). Result From PISA 2018. Retrieved from Result From PISA 2018: https://www.oecd.org/pisa/publications/PISA2018_CN_IDN.pdf

Pratiwi, I. (2019). Effect of PISA Program on Curriculum in Indonesia. Journal Education and Culture, 4(1), 51-71.

Rahma, A. (2015). The Effect of Smartphone Use on Student Life Activities (Case Study of MAN 1 Rengat Barat). Let's Fisip, 2(2), 1-12.

Rahma, N. M., Pratiwi, R. N., V.A, N. L. (2015). Strategy to Increase Children's Interest in Reading (Study in Children's Reading Room, Public Library and Regional Archives of Malang City). Journal of Public Administration, 3(5), 763-769.

Rohman, S. (2017). Building a Reading Culture in Children Through the School Literacy Movement Program. Journal of Basic Education and Learning, 4(1), 151-174.

Samniah, N. (2016). Ability to Understand Reading Content for Class VII Students of Private MTS Labibia. Journal of Humanika, 1(16), 1-16.

Sobon, K., Mangundap, J. M., Walewangko, S. (2019). The Effect of Smartphone Use on Learning Motivation of Elementary School Students in Mapanget District, Manado City. Journal of Basic Education Development, 3(2), 97-106.

Sugiyono. (2019). Quantitative Research Methods. Bandung ALFABETA, cv.

Sukardi. (2020). Analysis of Reading Interest Between EBooks and Printed Books Using the Observation Method at Tri Mitra Karya Mandiri Polytechnic. Journal of IKRA-ITH Economics, 4(2), 158-163.

Susanti, D., Santi. (2019). Utilization of Community Reading Gardens (TBM) in Increasing Youth Reading Interest (Case Study at TBM Gunung Ilmu). Comm-Edu Journal, 2(3), 220-226. 
Susanti, Y., Wibowo, D. C., Utami, R. D. (2018). Analysis of Students' Reading in High Grades at State Elementary School 01 Belitang. Journal of Basic Education PerKhasa, 4(1), 179-188.

Tantri, A. A., Dewantara, I. P. (2017). The Effectiveness of Literacy Culture at SD N 3 Banjar Jawa to Increase Reading Interest. Journal of Education Research and Evaluation, 1(4), 204-209.

Thresia, F. (2014). Evaluation of Student Reading Interest in Metro City. Tarbawiyah Journal, 11(2), 278-291 